\title{
BURDEN DISTRIBUTION OF A BROAD-BASED PERSONAL INCOME TAX SYSTEM AND ITS IMIPLICATIONS FOR TAX REFORM DISCUSSIONS
}

\author{
Attiat F. Ott, David J. Otr, and J. Scotr Turner*
}

Recent tax reform discussions have centered around two major areas of concern: first, the income base subject to the income tax, and, second, the rate at which income should be taxed. ${ }^{1}$ As an alternative to the present income base definition, some proponents of reform have suggested a "broader" base that closely approximates the Haig-Simons definition of income. ${ }^{2}$ This approach involves the inclusion in the base of some presently excluded income items such as interest on state and local bonds, gifts, bequests, devises and inheritances, and so forth; the recognition of appreciation and depreciation in the values of property as income subject to tax; and, finally, the addition to the base of items of imputed income attributable to property ownership or service-yielding assets (for example, imputed rent on owneroccupied houses).

With respect to the rate structure, however, little agreement exists among tax reform advocates on the proper rate structure or how the present rate structure might be modified. Galvin, Ture, and Stockfisch ${ }^{3}$ have suggested the substitution of a flat (proportionate) income tax rate for the existing "progressive" rate structure. A flat rate would eliminate distortion caused by progression, eliminate the need for relief measures for those taxpayers subject to higher rates, eliminate the bunching problem, and lead to simplification of the tax code. These arguments and the fact that rate progression cannot be justified on a sound "theoretical" basis make a flat rate structure appealing. However, such a proposal must also be evaluated in terms of the differential incidence of this tax system as opposed to the present one-that is, how many gain and how many lose by the substitution, and how the gainers and losers are distributed by income class.

The purpose of this paper is to present empirical evidence on the distribution of

*The authors are, respectively, Associate Professor of Economics, Clark University; Professor of Economics, Clark University; and Assistant Professor of Management, Oklahoma State University. The authors would like to acknowledge the assistance and the free computer service provided for them at Oklahoma State University. Research in the area was made possible by a grant from the Fund for Public Policy Research.

${ }^{1}$ C. Galvin \& B. Bittrer, The Income Tax: How Progressive Should It Be? (i969).

${ }^{3}$ Musgrave, In Defense of an Income Concept, 81 Harv. L. Rev. 44 (1967); Pechman, Comprehensive Income Taxation: A Comment, 8I HARv. L. REv. 63 (I967); Galvin, More on Boris Bittker and the Comprehensive Tax Base: The Practicalities of Tax Reform and the ABA's CSTR, 8I Harv. L. REv. ror6 (I968); Bittker, A 'Comprehensive Tax Base' as a Goal of Income Tax Reform, 80 HArv. L. REv. 925 (I967).

${ }^{3}$ Galvin, supra note 2, at Iox9; Ture, The Rate Structute of the Income Tax, Federal Tax Changes FOR THE Future, especially I6-19 (I970); Statement of J.A. Stockfisch, Hearings on Tax Reform Before the House Comm. on Ways and Means, 9Ist Cong., Ist Sess., pt. I2, at 4453-54 (1969). 
the tax burden that results from three hypothetical tax systems which involve the broadening of the federal personal income tax base and substitution of a "flat" tax rate structure, or, alternatively, a mildly progressive rate structure, for the rate schedule in effect prior to the 1969 Tax Reform Act. ${ }^{4}$ In Section I an outline of the "broad" base and the rate structures used in the study is given. Section II summarizes the methodology used in the estimates. The major findings of the study are highlighted in Section III, and some implications for tax reform discussions are then indicated in Section IV.

\section{I}

The Income Base and Rate Structure

The "broad" income tax base considered in this study is defined as the income generated through private market transactions or which would be generated through private market transactions. ${ }^{5}$ This includes factor income (cash and in kind), private transfer payments, and changes in net values of assets. In other words, starting with adjusted gross income (AGI), net of realized capital gains, as the base, we then include excluded factor incomes such as interest on state and local bonds, imputed rent, sick pay, and interest on life insurance cash surrender values; private transfers such as profit sharing and employers' contributions to retirement plans; and all gains on capital assets.

Given the "broad" tax base defined above, we then develop three alternative systems yielding the I 966 personal tax revenue (taxes before credits). Two of these use a flat rate structure, while the third is a simplified progressive rate structure with a maximum rate bracket of forty per cent. Alternative $A$ differs from the present personal income tax system (Ig66 tax law) in that it (I) allows $\$ 600$ exemptions for taxpayers and their dependents but no old age or blind exemptions and (2) disallows itemized deductions but provides a liberalization of the standard deduction. ${ }^{\circ}$

In Alternative $B$, the ten per cent standard deduction is replaced by a "low income allowance" and "percentage standard deduction" set forth for 1973 and after in the 1969 Tax Reform Act. The allowable personal exemption is raised to $\$ 625$ instead of $\$ 600$. The percentage standard deduction allows a deduction of fifteen per cent up to a maximum of $\$ 2000$, and the low income allowance is equal to the sum of the basic allowance plus the additional allowances. The basic allowance is an amount equal to the sum of $\$ 200$ plus the number of exemptions multiplied by $\$ 100$. However, the basic allowance cannot exceed \$rooo. The additional allowance is an

\footnotetext{
'Pub. L. No. 91-172 (Dec. 30, 1969).

- This definition excludes nonprivate (government) nonmarket transactions such as government transfer payments. Government transfer payments are simply another tool used to redistribute income and thus should be considered within the context of a tax-transfer system.

- $10 \%$ of income, up to a maximum of $\$ 2,000$.

7 The low income allowance chosen here is the one in the Tax Reform Act of 1969 , effective for I970. See Tax Reform Act of 1969, \$802.
} 
amount equal to the excess (if any) of \$goo over the sum of \$100, multiplied by the number of exemptions, plus the income phase-out, which is an amount equal to one-half of the amount by which the adjusted gross income exceeds $\$ \mathrm{r}, \mathrm{I}$, 00 plus $\$ 625$ multiplied by the number of exemptions. The low income allowance is used whenever it exceeds the percentage deduction.

Alternative $\mathrm{C}$ involves the same tax base as Alternative $\mathrm{B}$ but replaces the flat rate with a graduated rate up to forty per cent. The amount of the $x 966$ tax revenues were also generated under this alternative.

II

\section{Data and General Methodology}

The basic data sources used in this study are the Treasury Department's I 966 Tax File Subsample (Tax File), a stratified sample of some 30,000 individual income tax returns; the Office of Economic Opportunity's I967 Survey of Economic Opportunity (SEO); and the Federal Reserve Board's 1963 Survey of Financial Characteristics of Consumers (Fed Sample). The Tax File provided our 1966 tax model, to which we have imputed certain income items that are wholly or partially excluded from the present income tax base. The SEO and Fed Sample provided the necessary information for making many of the needed income imputations to broaden the income tax base.

Before the imputations could be made, however, we had to deal with two important problems. First, we had to sort out nonfilers (nontaxpaying families and unrelated individuals) from the SEO. Second, the Tax File had to be put on a family rather than a taxpayer basis. These steps were essential to make the two samples as comparable as possible. ${ }^{8}$

The procedure followed in imputing to the Tax File an income item was as follows: (I) ascertaining the aggregate amount of income to be added to the present tax base; (2) using the SEO or Fed Sample to allocate it by income class; (3) determining the conditional probability that any tax return would have the income being imputed; and (4) imputing it. The tax model was then used to estimate the distributional consequences of alternative tax systems $A$ and $B$ as compared to the existing system.

\section{III}

Summary of Major Findings

\section{A. Alternative A}

Under Alternative A, the addition to AGI (less realized capital gains) of seven income items excluded under $x 966$ tax law, adds $\$$ iI6 billion to the tax base. ${ }^{9}$ The

\footnotetext{
${ }^{8}$ The methodologies used are similar to those followed in Ott \& Ott, Simulation of Revenuse and Tax Structure Implications of Broadening the Federal Income Tax Base, in Studres in Substantive Tax REFORM 27-106 (A. Willis ed. 1969).

${ }^{0}$ The personal income tax base in 1966 was raised from $\$ 287$ billion to $\$ 403$ billion. The items added
} 
bulk of the gain in the tax base (eighty-five per cent) comes from three sourcescapital gains, imputed rent, and replacement of itemized deductions with the standard deduction. Since personal income tax revenues (before the credits) in 1966 were $\$ 58$ billion, the broader tax base made it possible to raise these r 966 revenues with a flat tax rate of 14.4 per cent.

The distribution pattern that resulted from the substitution of Alternative $A$ for the existing base and rate structure is shown in Tables I through 3. Table I shows by income class ${ }^{10}$ the number of returns filed in 1966 which would incur a

TABLE I

Distribution of Returns with Increased Tax Liability Under Alternative A, Broad Tax Base and a Flat Tax Rate of i4.4 Per Cent

(Thousands)

\begin{tabular}{|c|c|c|c|c|c|c|c|}
\hline \multirow[b]{2}{*}{ Income Class S } & \multicolumn{5}{|c|}{$\begin{array}{l}\text { Number of Returns Whose Tax Liability Is } \\
\text { Increased by: }\end{array}$} & \multirow{2}{*}{$\begin{array}{c}\text { Total } \\
\text { Number } \\
\text { of } \\
\text { Returns }\end{array}$} & \multirow{2}{*}{$\begin{array}{c}\text { S Avorago } \\
\text { Tax } \\
\text { Increase } \\
\text { per } \\
\text { Retura }\end{array}$} \\
\hline & $0-1 \%$ & $1-5 \%$ & $5-10 \%$ & $10-20 \%$ & $20 \%-\mathrm{ON}$ & & \\
\hline 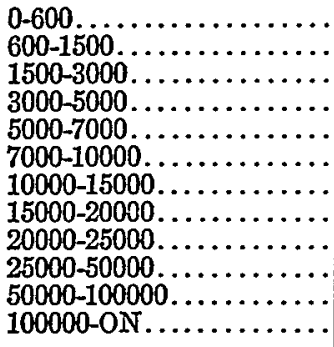 & $\begin{array}{r}0 \\
0 \\
127 \\
190 \\
163 \\
301 \\
124 \\
56 \\
20 \\
14 \\
2 \\
1\end{array}$ & $\begin{array}{r}0 \\
38 \\
522 \\
577 \\
758 \\
1227 \\
844 \\
233 \\
94 \\
45 \\
1 \\
8\end{array}$ & $\begin{array}{r}0 \\
12 \\
552 \\
418 \\
803 \\
1199 \\
848 \\
180 \\
62 \\
55 \\
2 \\
10\end{array}$ & $\begin{array}{r}0 \\
12 \\
1273 \\
735 \\
1174 \\
1619 \\
1092 \\
281 \\
108 \\
92 \\
11 \\
29\end{array}$ & $\begin{array}{r}0 \\
5351 \\
5011 \\
4994 \\
3816 \\
4058 \\
1860 \\
390 \\
163 \\
167 \\
19 \\
97\end{array}$ & $\begin{array}{r}0 \\
5413 \\
7485 \\
6914 \\
6719 \\
8404 \\
4858 \\
1140 \\
447 \\
373 \\
35 \\
145\end{array}$ & $\begin{array}{r}0 \\
31 \\
69 \\
115 \\
142 \\
161 \\
217 \\
329 \\
445 \\
863 \\
2280 \\
15165\end{array}$ \\
\hline TOTAL.............. & 1093 & 4347 & 4141 & 6426 & 25926 & 41933 & 191 \\
\hline
\end{tabular}

Increase in Tax Revenue from These Raturns $=\$ \$, 015,305,000$

larger tax liability and the average dollar increase in tax liability. For example, 390,000 returns (thirty-four per cent of the total with income between $\$ 15,000$ and $\$ 20,000$ ) would have an increase in personal tax liability under Alternative $\mathrm{A}$ of twenty per cent or more. The average dollar increase in tax liability for these returns is $\$ 329$. The total number of returns with increased tax liabilities is $4 \mathrm{r} .9$ million, and the average dollar increase in tax liability for these returns is \$rgr.

Table 2 gives the same type of information as Table I for returns with decreased tax liabilities. The total number of returns with decreased tax liability using Alternative $A$ is 28.2 million and the average dollar decrease in tax liability per return is $\$ 284^{11}$

to the base were the following: ( $x$ ) interest on state and local bonds; (2) employers' contributions to retirement plans; (3) profit sharing; (4) imputed rent on owners' occupied homes; (5) interest on life insurance surrender value; (6) sick pay; and (7) accrued capital gains on corporate stock.

${ }^{10}$ Income includes the imputed income items required to broaden the tax base.

${ }^{11}$ Note that the flat rate of $14.4 \%$ was chosen in such a way that the increased tax liability would cqual 
From Tables $I$ and 2 it is clear that if Alternative A had replaced the 1966 tax code in 1966, eleven per cent of all returns would have had a tax change between minus one per cent and plus one per cent, twenty-four per cent of the returns would have a tax change between minus twenty per cent and plus twenty per cent, and forty-four per cent would either pay more or less than twenty per cent of what they were currently paying.

TABLE 2

Distribution of Returns with Decreased Tax Liability Under Alternative A, Broad Tax Base and a Flat Rate of 44.4 Per Cent

(Thousands)

\begin{tabular}{|c|c|c|c|c|c|c|c|}
\hline \multirow[b]{2}{*}{ Income Class S } & \multicolumn{5}{|c|}{$\begin{array}{l}\text { Number of Returns Whose Tax Liability Is } \\
\text { Decreased by: }\end{array}$} & \multirow{2}{*}{$\begin{array}{l}\text { Total } \\
\text { Number } \\
\text { of } \\
\text { Returns }\end{array}$} & \multirow{2}{*}{$\begin{array}{l}\text { S Aversge } \\
\text { Tax } \\
\text { Decrease } \\
\text { per } \\
\text { Return }\end{array}$} \\
\hline & $0-1 \%$ & $1-5 \%$ & $5-10 \%$ & $10-20 \%$ & $20 \%$-ON & & \\
\hline 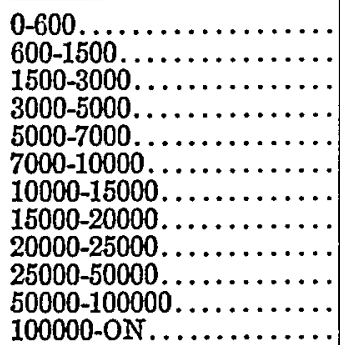 & $\begin{array}{r}3782 \\
1378 \\
65 \\
135 \\
148 \\
313 \\
214 \\
49 \\
12 \\
21 \\
1 \\
2\end{array}$ & $\begin{array}{r}0 \\
0 \\
409 \\
969 \\
834 \\
1461 \\
1013 \\
263 \\
84 \\
63 \\
5 \\
6\end{array}$ & $\begin{array}{r}0 \\
0 \\
375 \\
751 \\
1017 \\
1467 \\
1495 \\
392 \\
134 \\
119 \\
9 \\
8\end{array}$ & $\begin{array}{r}0 \\
0 \\
12 \\
1744 \\
872 \\
1585 \\
1918 \\
667 \\
291 \\
234 \\
24 \\
13\end{array}$ & $\begin{array}{r}0 \\
0 \\
1115 \\
304 \\
224 \\
385 \\
615 \\
382 \\
239 \\
439 \\
134 \\
38\end{array}$ & $\begin{array}{l}3782 \\
1378 \\
1976 \\
3903 \\
3095 \\
5211 \\
5255 \\
1753 \\
760 \\
876 \\
173 \\
118\end{array}$ & $\begin{array}{r}0 \\
0 \\
6 \\
41 \\
65 \\
99 \\
179 \\
326 \\
568 \\
1392 \\
4249 \\
27576\end{array}$ \\
\hline TOTAL. & 6120 & 5107 & 5767 & 7360 & 3926 & 28280 & 284 \\
\hline
\end{tabular}

Decrease in Tax Revenue from These Returns $=\$ 8,031,520,000$

A comparison of the number of returns with increased tax liability (losers) with the number of returns with decreased tax liability (gainers) is shown in Table 3 . The fourth column in the table gives the net number of returns with increased taxes. A negative figure in that column indicates that there are more returns in the income class with decreased taxes than there are with increased taxes. As Table 3 indicates, returns with increased tax liabilities outnumber those with decreased tax liabilities for income classes between $\$ 600$ and $\$ 10,000$, and for the income class of $\$ 100,000$ and on. Furthermore, some sixty-nine per cent of all returns with incomes between $\$ 600$ and $\$ 10,000$ would pay more taxes using Alternative $A$ than they would pay under the I 966 tax code, and approximately forty-four per cent of the returns with incomes over $\$$ Io,000 would pay more taxes using Alternative $A$. Out of all returns, sixty per cent would have a larger tax liability and forty per cent

the decreased tax liability. The increase in tax is given by $(4 \mathrm{r}, 933,000) \times(\$ \mathrm{rg} \mathrm{r})=\$ 8,0 \mathrm{r} 5$ million and the decrease in $\operatorname{tax}$ is given by $(23,280,000) \times(\$ 284)=\$ 8,032$ million. The $\$ 17$ million discrepancy is due to rounding off of the flat rate and to the fact that the data set is not perfectly uniform in its composition of returns. 
TABLE 3

Comparison of Returns with an Increased Tax Liability with Those with $A$ Reduced Tax Liability Under Alternative A

\begin{tabular}{|c|c|c|c|}
\hline \multirow[b]{2}{*}{ Income Class \$ } & \multicolumn{2}{|c|}{ Number of Returns (Thousands) } & \multirow{2}{*}{$\begin{array}{l}\text { Excess of Roturns } \\
\text { with Increased Taxe } \\
\text { over Returns with } \\
\text { Reduced Taxes } \\
\text { (Thoussnds) }\end{array}$} \\
\hline & $\begin{array}{c}\text { with } \\
\text { Increased Taxes }\end{array}$ & $\begin{array}{c}\text { with } \\
\text { Reduced Taxes }\end{array}$ & \\
\hline 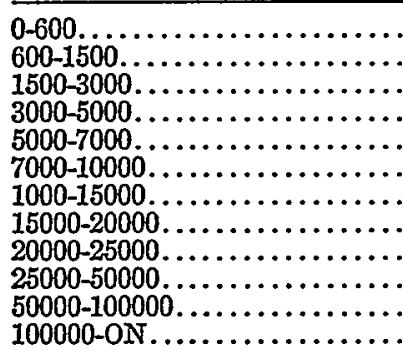 & $\begin{array}{r}0 \\
5413 \\
7485 \\
6914 \\
6719 \\
8404 \\
4858 \\
1140 \\
447 \\
373 \\
35 \\
145\end{array}$ & $\begin{array}{r}3782 \\
1378 \\
1976 \\
3903 \\
3095 \\
5211 \\
5255 \\
1753 \\
760 \\
876 \\
173 \\
118\end{array}$ & $\begin{array}{r}-3782 \\
4035 \\
5509 \\
3011 \\
3624 \\
3193 \\
-397 \\
-613 \\
-313 \\
-503 \\
-138 \\
27\end{array}$ \\
\hline TOTAL................... & 41933 & 28280 & 13635 \\
\hline
\end{tabular}

would have a reduced tax liability. Increased net tax payments for returns with incomes below $\$$ ro,000 would generate an additional $\$ 2.9$ billion; returns with incomes greater than $\$ 10,000$ would have a net reduction in tax liability of $\$ 2.9$ billion.

In short, Alternative A clearly benefits some individuals and families with incomes in excess of $\$ 10,000$ at the expense of some of those individuals and families with incomes below $\$ 10,000$. The explanation for this result is that individuals and families with incomes less than \$ro,000 paid less than 14.4 per cent of their "broad" taxable income in I966, whereas those persons and families with incomes in excess of \$10,000 paid, on the average, more than 14.4 per cent of their "broad" taxable incomes.

\section{B. Alternative B}

Under Alternative B the tax base increased from $\$ 287$ billion, in I966, to $\$ 376$ billion. ${ }^{12}$ The flat income tax rate required to generate $\mathrm{I} g 66$ tax revenues (before credit) is 15.4 per cent. The distributional effects of Alternative B-whose tax liability increased, and whose decreased-are shown in Tables 4 and 5. Table 6 summarizes the net distributional pattern.

Approximately $4 \mathrm{I} .7$ million returns would have a decreased tax liability if Alternative B were used in place of the Ig66 tax code. Of this total, 4.9 million returns would have had a decrease of less than one per cent. The average dollar decrease in tax liability per return would have been $\$ 186$. If those returns with a

\footnotetext{
${ }^{19}$ The increase in the base is only $\$ 89$ billion as compared to $\$ x I 6$ billion under Alternative $A$. This is due to the increased level of personal exemption, a higher standard deduction, and the low income - allowance allowed under Alternative B.
} 
TABLE 4

Distribution of Returns with Decreased Tax Liability Under Alternative B, Broad Tax Base and a Flat Rate of 15.4 Per Cent

(Thousands)

\begin{tabular}{|c|c|c|c|c|c|c|c|}
\hline \multirow[b]{2}{*}{ Income Class S } & \multicolumn{5}{|c|}{$\begin{array}{l}\text { Number of Returns Whose Tax Iiability Is } \\
\text { Decreased by: }\end{array}$} & \multirow{2}{*}{$\begin{array}{c}\text { Total } \\
\text { Number } \\
\text { of } \\
\text { Returns }\end{array}$} & \multirow{2}{*}{$\begin{array}{c}\text { S Average } \\
\text { Tax } \\
\text { Decrease } \\
\text { per } \\
\text { Return }\end{array}$} \\
\hline & $0-1 \%$ & $1-5 \%$ & $5-10 \%$ & $10-20 \%$ & $20 \%$-ON & & \\
\hline 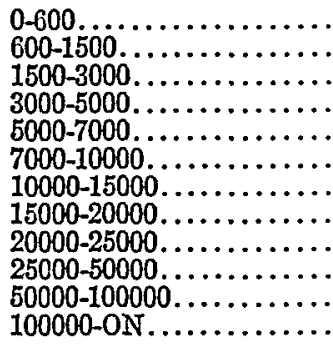 & $\begin{array}{r}3782 \\
0 \\
0 \\
139 \\
186 \\
443 \\
273 \\
66 \\
33 \\
20 \\
0 \\
2\end{array}$ & $\begin{array}{r}0 \\
0 \\
49 \\
1008 \\
697 \\
1371 \\
1007 \\
274 \\
104 \\
89 \\
9 \\
5\end{array}$ & $\begin{array}{r}0 \\
0 \\
135 \\
0139 \\
1119 \\
1594 \\
1549 \\
425 \\
136 \\
119 \\
15 \\
5\end{array}$ & $\begin{array}{r}0 \\
0 \\
716 \\
1999 \\
811 \\
1653 \\
1888 \\
575 \\
255 \\
218 \\
14 \\
12\end{array}$ & $\begin{array}{r}0 \\
6792 \\
7217 \\
1708 \\
410 \\
345 \\
556 \\
242 \\
113 \\
309 \\
125 \\
83\end{array}$ & $\begin{array}{r}3782 \\
6792 \\
8117 \\
5893 \\
3223 \\
5406 \\
5273 \\
1582 \\
641 \\
755 \\
163 \\
107\end{array}$ & $\begin{array}{r}0 \\
16 \\
48 \\
36 \\
60 \\
93 \\
172 \\
292 \\
484 \\
1272 \\
3941 \\
28902\end{array}$ \\
\hline TOTAL..... & 4944 & 4613 & 6136 & 8141 & 17900 & 41734 & 186 \\
\hline
\end{tabular}

Decrease in Tax Revenue from These Returns $=\$ 7,762,000,000$

decrease of less than one per cent are excluded, the average dollar decrease in tax liability per return is \$2Ir.

Some 28.5 million returns would have incurred an increased tax liability with an average dollar increase per return of $\$ 272 .^{13}$

Table 6 gives the profile of the percentage change in the tax liability which would have occurred in Ig66 if Alternative B had replaced the existing code. These changes are given by income classes, and the calculations were made using the data in Tables 4 and 5 .

Observing the bottom, or "total" row in Table 6, the general characteristics of the percentage changes can be determined. For example, eight per cent of all returns under Alternative B would be affected by less than one per cent; thirteen per cent would be changed between on and five per cent or between minus one and minus five per cent. The percentage which would be affected by five to ten per cent or minus five to minus ten per cent would be fourteen per cent. Only thirty-five per cent of all returns would experience a change in tax liability between minus ten per cent and plus ten per cent. While twenty per cent of filers would incur an additional tax of more than twenty per cent, twenty-five per cent would have a tax reduction of more than twenty per cent.

${ }^{13}$ The flat rate of $15.4 \%$ was chosen in such a way that the total increase in tax is equal to the total decrease in tax liability using Alternative $B$. The increase is $(28,487,000) \times(\$ 272)=\$ 7,748$ million, and the decrease is $(4 \mathrm{I}, 734,000) \times(\$ 186)=\$ 7,762$ million. The $\$ 14$ million discrepancy is due to rounding off of the flat rate and to the fact that the data set is not perfectly uniform in its composition of different returns. 
TABLE 5

Distribution of Returns with Increased Tax Liabiltty Under Alternative B, Broad Tax Base and a Flat Rate of 15.4 Per Cent

(Thousands)

\begin{tabular}{|c|c|c|c|c|c|c|c|}
\hline \multirow[b]{2}{*}{ Income Class S } & \multicolumn{5}{|c|}{$\begin{array}{l}\text { Number of Returns Whose Tax Liability Is } \\
\text { Increased by: }\end{array}$} & \multirow{2}{*}{$\begin{array}{l}\text { Total } \\
\text { Number } \\
\text { of } \\
\text { Returns }\end{array}$} & \multirow{2}{*}{$\begin{array}{c}8 \text { Averago } \\
\text { Tax } \\
\text { Increaso } \\
\text { por } \\
\text { Return }\end{array}$} \\
\hline & $0-1 \%$ & $1-5 \%$ & $5-10 \%$ & $10-20 \%$ & $20 \%-O N$ & & \\
\hline 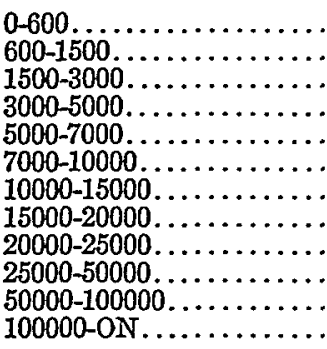 & $\begin{array}{r}0 \\
0 \\
12 \\
134 \\
202 \\
307 \\
192 \\
83 \\
19 \\
21 \\
1 \\
2\end{array}$ & $\begin{array}{r}0 \\
0 \\
97 \\
612 \\
986 \\
1247 \\
853 \\
206 \\
91 \\
73 \\
4 \\
6\end{array}$ & $\begin{array}{r}0 \\
0 \\
41 \\
499 \\
430 \\
830 \\
1075 \\
872 \\
257 \\
96 \\
68 \\
8 \\
7\end{array}$ & $\begin{array}{r}0 \\
0 \\
72 \\
716 \\
1064 \\
1676 \\
1089 \\
313 \\
145 \\
96 \\
3 \\
21\end{array}$ & $\begin{array}{r}0 \\
0 \\
1123 \\
2967 \\
3508 \\
3904 \\
1833 \\
454 \\
214 \\
238 \\
30 \\
120\end{array}$ & $\begin{array}{r}0 \\
0 \\
1345 \\
4928 \\
6590 \\
8209 \\
4839 \\
1313 \\
565 \\
496 \\
46 \\
156\end{array}$ & $\begin{array}{r}0 \\
0 \\
71 \\
109 \\
133 \\
161 \\
222 \\
334 \\
480 \\
904 \\
2332 \\
16496\end{array}$ \\
\hline TOTAL. & 973 & 4175 & 3753 & 5195 & 14391 & 28487 & 272 \\
\hline
\end{tabular}

Increase in Tax Revenue from These Returns $=\$ 7,748,000,000$

TABLE 6

Profile of Changes in Taxes (as a Percentage of Previous Taxes) Under Alternative B, Broad Tax Base and a Flat Rate of 15.4 Per Cent

\begin{tabular}{|c|c|c|c|c|c|c|c|c|c|c|c|}
\hline \multirow{2}{*}{$\begin{array}{c}\text { Income } \\
\text { Class } \\
\$\end{array}$} & \multicolumn{10}{|c|}{ Percentage of Returns Whose Change in Tax Liability Is: } & \multirow{2}{*}{$\begin{array}{c}\text { Total } \\
\text { Number } \\
\text { of Roturns } \\
\text { (Thousands) }\end{array}$} \\
\hline & $\begin{array}{l}-20 \% \\
-O N\end{array}$ & \begin{tabular}{|l}
-10 to \\
$-20 \%$
\end{tabular} & $\begin{array}{r}-5 \text { to } \\
-10 \%\end{array}$ & $\begin{array}{l}-1 \text { to } \\
-5 \%\end{array}$ & $\begin{array}{l}0 \text { to } \\
-1 \%\end{array}$ & $\begin{array}{l}0 \text { to } \\
1 \%\end{array}$ & $\begin{array}{l}1 \text { to } \\
5 \%\end{array}$ & $\begin{array}{l}5 \text { to } \\
10 \%\end{array}$ & $\begin{array}{l}10 \text { to } \\
20 \%\end{array}$ & $\begin{array}{l}20 \% \\
-O N\end{array}$ & \\
\hline $\begin{array}{l}0-600 \\
600-1500 \\
1500-3000 \\
3000-5000 \\
5000-7000 \\
7000-10000 \\
10000-15000 \\
15000-20000 \\
20000-25000 \\
25000-50000 \\
50000-100000 \\
100000-0 N\end{array}$ & $\begin{array}{r}76 \\
16 \\
4 \\
3 \\
5 \\
8 \\
9 \\
25 \\
60 \\
32\end{array}$ & $\begin{array}{r}8 \\
18 \\
8 \\
12 \\
19 \\
20 \\
21 \\
17 \\
7 \\
5\end{array}$ & $\begin{array}{r}1 \\
9 \\
11 \\
12 \\
15 \\
15 \\
11 \\
10 \\
7 \\
2\end{array}$ & $\begin{array}{r}1 \\
9 \\
7 \\
10 \\
10 \\
9 \\
9 \\
7 \\
4 \\
2\end{array}$ & $\begin{array}{r}100 \\
100 \\
0 \\
1 \\
2 \\
3 \\
3 \\
2 \\
3 \\
2 \\
0 \\
1\end{array}$ & $\begin{array}{l}0 \\
1 \\
2 \\
2 \\
2 \\
3 \\
2 \\
2 \\
0 \\
1\end{array}$ & $\begin{array}{r}1 \\
6 \\
10 \\
9 \\
8 \\
7 \\
8 \\
6 \\
2 \\
2\end{array}$ & $\begin{array}{l}0 \\
5 \\
8 \\
8 \\
9 \\
9 \\
8 \\
5 \\
4 \\
2\end{array}$ & $\begin{array}{r}1 \\
7 \\
11 \\
12 \\
11 \\
11 \\
12 \\
8 \\
1 \\
8\end{array}$ & $\begin{array}{l}12 \\
27 \\
36 \\
29 \\
18 \\
16 \\
18 \\
19 \\
14 \\
46\end{array}$ & $\begin{array}{r}3782 \\
6702 \\
9462 \\
10821 \\
9813 \\
13615 \\
10112 \\
2895 \\
1206 \\
1251 \\
209 \\
263\end{array}$ \\
\hline TOTAL & 25 & 12 & 9 & 7 & 7 & 1 & 6 & $\mathbf{5}$ & 7 & 20 & 70221 \\
\hline
\end{tabular}

The over-all pattern of distribution of tax liability that results from Alternative $B$ is shown in Table 7. In the table we compare the "gainers" and "losers" by income class. Gainers outnumber losers in most income classes. The total number of returns which would benefit from Alternative B is $4 \mathrm{r} .7$ million (59.x per cent of the total) compared to 28.5 million returns (forty-one per cent of the total) which would 
TABLE 7

Comparison of Returns with an Increased Tax Liability with Those with a Reduced Tax Liability Under Alternative B

\begin{tabular}{|c|c|c|c|}
\hline \multirow[b]{2}{*}{ Income Class 8} & \multicolumn{2}{|c|}{ Number of Returns (Thousands) } & \multirow{2}{*}{$\begin{array}{l}\text { Excess of Returns } \\
\text { with Increased } \\
\text { Taxes over Returns } \\
\text { with Reduced Taxes } \\
\text { (Thousands) }\end{array}$} \\
\hline & $\begin{array}{c}\text { with } \\
\text { Increased Taxes }\end{array}$ & $\begin{array}{c}\text { with } \\
\text { Reduced Taxes }\end{array}$ & \\
\hline 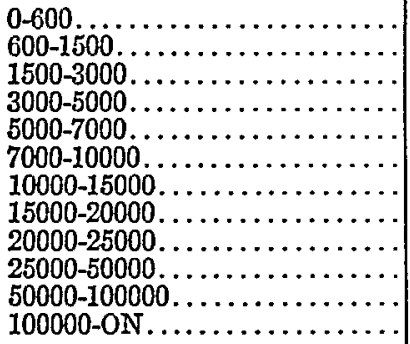 & $\begin{array}{r}0 \\
0 \\
1345 \\
4928 \\
6590 \\
8209 \\
4839 \\
1313 \\
565 \\
496 \\
46 \\
156\end{array}$ & $\begin{array}{r}3782 \\
6792 \\
8117 \\
5893 \\
3223 \\
5406 \\
5273 \\
1582 \\
641 \\
755 \\
163 \\
107\end{array}$ & $\begin{array}{r}-3782 \\
-6792 \\
-6772 \\
-965 \\
3367 \\
2803 \\
-434 \\
-269 \\
-76 \\
-259 \\
-117 \\
49\end{array}$ \\
\hline TOTAL...$\ldots \ldots \ldots \ldots \ldots \ldots$ & 28487 & 41734 & -13247 \\
\hline
\end{tabular}

lose under it. ${ }^{14}$ Column 4 in Table 7 gives the net increase in the number of returns with an increased tax liability. A negative figure in Column 4 indicates that the number of returns with decreased tax liabilities is greater than the number of returns with increased tax liabilities in that income class.

From Table $7 \mathrm{t}$ is clear that taxpayers in all income classes, with the exception of those in the $\$ 5000$ to $\$ 7000, \$ 7000$ to $\$ 10,000$, and $\$ 100,000$ and over brackets, gain under Alternative $B$ as compared to the existing tax structure. The net increase in tax liability for the interval $\$ 5000$ to $\$$ ro,000, calculated from Tables 4 and 5 , is $\$ 2.0$ billion. On the other hand, there would be a net reduction of $\$ \mathrm{r} .9$ billion in tax liability for returns with incomes greater than \$10,000 (also calculated from Tables 4 and 5). This \$r.9 billion net reduction is broken into a net reduction of \$r.4 billion for the income interval $\$ 10,000$ to $\$ 100,000$, and a net reduction of $\$ .5$ billion for the income class $\$ 100,000$ and above..$^{15}$

The net gain for returns with incomes less than $\$ 5000$ is $\$ . I$ billion. Some 6.3 million returns with income less than $\$ 5000$ whose tax liability increased generate an additional $\$ .6$ billion in taxes, whereas the 24.6 million returns in this income class with decreased taxes receive a total tax reduction of $\$ .7$ billion.

If all returns with incomes less than $\$ 1500$ or greater than $\$ 100,000$ are excluded, approximately fifty-two per cent of the returns remaining would show a reduction in tax liability. ${ }^{16}$ It is also interesting to note that the average decrease in the tax,

\footnotetext{
14 The data in Table 7 came from the "Total" columns in Tables 4 \& supra.

${ }^{15}$ Note that the number of returns with increased tax liability is some $50 \%$ greater than the number of returns with decreased taxes for the income class \$ro0,000 and up. However, the net change in tax liability favors those with a reduction in taxes. The increase in tax for this income class is $(156,000)$ $\times(\$ 16,496)=\$ 2.6$ billion. The decrease in tax for the same income class is $(107,000) \times(\$ 28,902)=$ \$3.I billion. So, the net change in tax for the $\$ 100,000$ and up income class is $-\$ .5$ billion.

${ }^{20}$ The income classes $\$ 0-\$ 600$ and $\$ 600-\$ 1500$ should be left out since the tax decrease per return
} 
for those with decreased taxes, is $\$ 129$, and the average increase in tax for returns with increased taxes is $\$ 183$ for returns with incomes greater than $\$ 1500$ but less than $\$ 100,000$.

Alternative $B$ is undoubtedly a better tax system than Alternative A. It may also be considered an improvement over the existing tax structure for it moves closer to the the goal of horizontal equity in taxation. For every income class, whether gainers have exceeded losers or vice-versa, Alternative B treats more equally taxpayers in equal circumstances than does the existing (Ig66) tax structure. Taxpayers who lose under Alternative B clearly lose because Alternative B eliminates the built-in preferences in the I 966 law for income derived from certain sources.

In short, horizontal equity is improved in every income class, by definition. When we add to this the fact that the number of gainers exceeds the number of losers, Alternative B is more attractive, for reasons of both equity and politics, than either Alternative $\mathrm{A}$ or the existing system.

\section{Alternative C}

Using the same base as that used under Alternative B (including the low income allowance), the graduated rate structure which is needed to raise the 1966 tax revenue is a simple one with a maximum rate of forty per cent. Table 8 gives the marginal rate structure which we linked to the data by income class.

TABLE 8

A Graduated Tax Rate of 10\%-40\%

\begin{tabular}{c|c}
\hline \hline Tax Base & Marginal Rate \\
\cline { 2 - 3 } $0-10,000$ & .10 \\
$10,000-15,000$ & .15 \\
$15,000-25,000$ & .21 \\
$25,000-50,000$ & .30 \\
$50,000-0 \mathrm{~N}$ & .40 \\
\hline
\end{tabular}

Tables 9 and ro show the total number of returns which would lose or gain under Alternative C. Had Alternative $C$ been employed in place of the $\mathrm{I} 966$ tax code, approximately 62 million returns would have been better off and only 8.5 million would have been worse off. The average dollar decrease in tax liability per return with a decreased liability would have been $\$ 242$. while the average increase per return with an increased liability would have been $\$ 1700$.

It is interesting to note that for income classes of $\$ 10,000$ and less, 57 million returns show a decreased tax liability as against only 7 million returns with increased tax liability. The average decrease in liability per return is $\$ 183$ as compared to $\$ 124$ for returns with a tax increase.

in these classes is negligible. In fact, it is zero for the class $\$ 0-\$ 600$, and only \$16 for the class $\$ 600$ $\$ 1500$. 
Table Ir gives the total number of gainers and losers if Alternative $C$ had been implemented in I966. From Table II it is clear that under Alternative $\mathrm{C}$ more returns would have had decreased tax liabilities for the tax base up to $\$ 25,000$. Tax returns with a tax base over $\$ 25,000$ would, on the whole, have had increased tax liabilities.

Of particular interest is the fact that, although the highest marginal rate used in the graduated structure is forty per cent, those with high incomes pay more taxes under this system than under our present tax system with a top rate of seventy per cent. This is due to the fact that the tax base used here is broader than the present income tax base, thus disallowing exclusions or otherwise preferential treatment awarded to those in higher marginal brackets. Clearly the graduated marginal

TABLE 9

Distribution of Returns With Increased Tax Liability Under Alternative C, Broad Tax Base and a Graduated Rate of I0\%-40\%* (Thousands)

\begin{tabular}{|c|c|c|c|c|c|c|c|}
\hline \multirow[b]{2}{*}{ Income Class S } & \multicolumn{5}{|c|}{ Number of Returns Whose Tax Liability Is Increased by: } & \multirow{2}{*}{$\begin{array}{c}\text { Total } \\
\text { Number } \\
\text { of } \\
\text { Returns }\end{array}$} & \multirow{2}{*}{$\begin{array}{c}\text { \$ } \\
\text { Average } \\
\text { Increase } \\
\text { Per Return }\end{array}$} \\
\hline & $0-1 \%$ & $1-5 \%$ & $5-10 \%$ & $10-20 \%$ & $20 \%-\mathrm{ON}$ & & \\
\hline 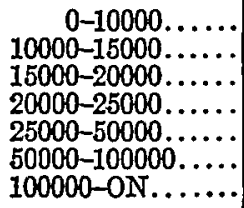 & $\begin{array}{r}164 \\
15 \\
18 \\
2 \\
12 \\
1 \\
.4\end{array}$ & $\begin{array}{r}536 \\
30 \\
31 \\
33 \\
73 \\
6 \\
1\end{array}$ & $\begin{array}{r}415 \\
38 \\
23 \\
22 \\
76 \\
7 \\
2\end{array}$ & $\begin{array}{r}684 \\
35 \\
45 \\
28 \\
156 \\
13 \\
2\end{array}$ & $\begin{array}{r}4953 \\
239 \\
101 \\
82 \\
372 \\
58 \\
193\end{array}$ & $\begin{array}{r}6752 \\
357 \\
218 \\
167 \\
689 \\
85 \\
198\end{array}$ & $\begin{array}{r}124 \\
463 \\
448 \\
691 \\
1545 \\
5329 \\
59000\end{array}$ \\
\hline TOTAL.......... & 212.4 & 710 & 583 & 963 & 5998 & 8466 & 1703 \\
\hline
\end{tabular}

* See Table 8.

TABLE Io

Distribution of Returns With Decreased Tax Liability Under Alternative C, Broad Tax Base and a Graduated Rate of 10\%-40\%*

(Thousands)

\begin{tabular}{|c|c|c|c|c|c|c|c|}
\hline \multirow[b]{2}{*}{ Income Class $S$} & \multicolumn{5}{|c|}{ Number of Returns Whose Tax Liability Is Decreased by: } & \multirow{2}{*}{$\begin{array}{c}\text { Total } \\
\text { Number } \\
\text { of } \\
\text { Returns }\end{array}$} & \multirow{2}{*}{$\begin{array}{c}\$ \\
\text { Average } \\
\text { Decrease } \\
\text { Per Return }\end{array}$} \\
\hline & $0-1 \%$ & $1-5 \%$ & $5-10 \%$ & $10-20 \%$ & $20 \%-\mathrm{ON}$ & & \\
\hline $\begin{array}{r}0-10000 \ldots . . . \\
10000-15000 \ldots . . \\
15000-20000 \ldots . . \\
20000-25000 \ldots . . \\
25000-50000 \ldots . . \\
50000-100000 . . . \\
100000-0 \mathrm{~N} . . .\end{array}$ & $\begin{array}{r}113 \\
10 \\
19 \\
9 \\
15 \\
1 \\
.3\end{array}$ & $\begin{array}{r}668 \\
51 \\
63 \\
37 \\
58 \\
8 \\
2\end{array}$ & $\begin{array}{r}989 \\
79 \\
112 \\
48 \\
48 \\
17 \\
2\end{array}$ & $\begin{array}{r}2668 \\
307 \\
335 \\
110 \\
59 \\
17 \\
7\end{array}$ & $\begin{array}{r}52160 \\
2818 \\
650 \\
163 \\
75 \\
24 \\
13\end{array}$ & $\begin{array}{r}56598 \\
3265 \\
1179 \\
367 \\
255 \\
67 \\
24\end{array}$ & $\begin{array}{r}183 \\
662 \\
659 \\
843 \\
1292 \\
3927 \\
30998\end{array}$ \\
\hline TOTAL..... & 167 & 887 & 1295 & 3503 & 55903 & 61755 & 242 \\
\hline
\end{tabular}

- See Table 8. 
TABLE II

Gatners, Losers, and Net Position Under Alternative C, Broad Tax Base and a Graduated Rate of 10\%-40\%

\begin{tabular}{|c|c|c|c|}
\hline \multirow[b]{2}{*}{ Income Class S } & \multicolumn{2}{|c|}{ Number of Returns (Thoussnds) } & \multirow{2}{*}{$\begin{array}{l}\text { Excess of Roturns } \\
\text { With Reduced } \\
\text { Taxes Over Returns } \\
\text { With Increased Taxes } \\
\text { (Thousands) }\end{array}$} \\
\hline & $\begin{array}{c}\text { with } \\
\text { Increased Taxes }\end{array}$ & $\begin{array}{c}\text { with } \\
\text { Reduced Taxes }\end{array}$ & \\
\hline 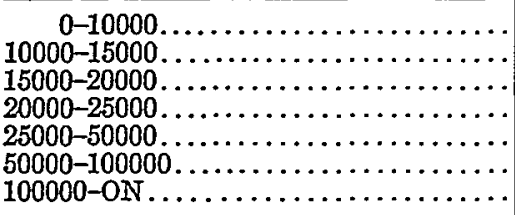 & $\begin{array}{r}6752 \\
357 \\
218 \\
167 \\
689 \\
85 \\
198\end{array}$ & $\begin{array}{r}56598 \\
3265 \\
1179 \\
367 \\
255 \\
67 \\
24\end{array}$ & $\begin{array}{r}-40840 \\
-2008 \\
-961 \\
-200 \\
434 \\
18 \\
174\end{array}$ \\
\hline TOTAL.. & 8466 & 61755 & -53280 \\
\hline
\end{tabular}

* See Table 8.

rate structure used here, when coupled with a broad tax base, is more progressive and achieves more equity in the distribution of the tax burden than the existing (Ig66) tax rate structure.

\section{IV}

\section{IMPLications for Tax Reform Discussion}

After comparing the existing income tax base and rate structure to the three hypothetical tax systems examined in this paper, it is evident that the design of a tax structure that broadens the base, coupled with a flat tax rate-if such a rate structure is desired-must be envisaged with the differential incidence, class by class, of the proposed and the old system in mind. From the data presented in this study, it would appear that a broad tax base coupled with a low income allowance, elimination of itemizing, and a flat tax rate helps the majority of taxpayers. However, it hurts more taxpayers in the $\$ 5000-$ to- $\$ 10,000$ and over- $\$ 100,000$ classes than it helps. When a graduated rate structure of ten per cent to forty per cent is substituted for the flat rate in Alternative $B$, more taxpayers in every income class up to $\$ 25,000$ are helped rather than hurt by it. The pattern of gainers and losers reported in all cases obviously reflects the combination of items added to the base ${ }^{17}$ and the specific pattern of deductions or allowances chosen. The alternatives suggested here are clearly used for illustrative purpose only. However, it would be possible to design a tax structure with a "broader" tax base, some form of low-middle income allowance, and an appropriate rate structure, which would result in a different pattern of distribution of gainers and losers. The distribution pattern resulting from Alternative $C$ is clearly more acceptable on equitable and moral grounds

\footnotetext{
17 The income items imputed to the tax base to arrive at the "broad" base in this study fall short of those outlined in our definition. The items selected were those items for which data are presently available. Estimations of other income items are presently under way.
} 
than the existing pattern of tax burden distribution. The important point, however, is that a goal of taxation and the distribution of the tax bill must be made explicit before designing any one particular tax system. If the tax system is to achieve horizontal equity then it must be constructed in such a way as to eliminate all preferences as to sources of income along the lines outlined in our broad base. When the loss of "preferences" imposes a hardship on certain groups of taxpayers, one should explicitly recognize whether the loss of "preferences" removes an already existing inequity with respect to the equal treatment of equals or imposes some hardship which the old tax system has been trying to alleviate on grounds other than equity in taxation (for example, itemized deductions for extraordinary medical bills). In the latter case one would argue that the tax system should not be used for this purpose. A transfer scheme built into the tax system might be designed to achieve such a purpose.

In summary, a properly defined income tax base is the first ingredient of any tax reform package. The rate structure--whether a flat rate, or a progressive rate with low income allowance or some other features (built-in transfers, for example)-could be constructed to meet the desired goal of after-tax/transfer income distribution. The appeal or lack of appeal of any new tax package, however, must ultimately rest on the distributional pattern it would achieve as compared to the existing one and on the extent such new patterns approximate the "desired" one. 